\title{
An expedient synthesis of 2,5-dihydroxytyrosol and studies on its effects on cell growth inhibition
}

\author{
Sergio Ammendola, ${ }^{\mathrm{a}}$ Luciana Mosca, ${ }^{\mathrm{b}}$ and Paolo Bovicelli ${ }^{\mathrm{c}^{*}}$ \\ ${ }^{a}$ AMBIOTEC sas, SS7 Km 50,610, I-04012 Cisterna di Latina (LT), Italy \\ ${ }^{b}$ Department of Biochemistry, Sapienza University, P.le A. Moro 5, I-00185 Rome, Italy \\ ${ }^{c}$ Institute for Biomolecular Chemistry, CNR, Dep. of Chemistry, Sapienza University, P.le A. \\ Moro 5, I-00185 Rome, Italy \\ E-mail: paolo.bovicelli@uniroma1.it
}

\section{Dedicated to Professor Arlette Solladié-Cavallo on her $\mathbf{7 0}^{\text {th }}$ birthday}

\begin{abstract}
Many antioxidant molecules are described to have an oxidant activity causing cell damages. Some dietary phytophenols, in spite of their beneficial effects, have been found to promote lipid peroxidation and DNA breaks. Hydroxytyrosol, a phytophenol extracted from olive oil and wine, has been found to act as an antioxidant. Furthermore it also inhibits the growth of several bacteria and fungi. During recent studies on the synthesis of antioxidant polyphenols from tyrosol, a phenol recovered in high amount from olive oil wastes, we prepared 2,4,5-trihydroxy(2-hydroxyethyl)-phenol (2,5-dihydroxytyrosol). We observed its biological effect on cultured human and bacterial cells showing that its toxic activity is more potent than tyrosol and hydroxytyrosol resulting toxicity at $5 \mu \mathrm{M}$ whereas its parent molecules are toxic at a dose of about $100 \mu \mathrm{M}$.
\end{abstract}

Keywords: Phenoxyl radical, lipid peroxidation, polyphenol, antioxidant, prooxidant, growth inhibition

\section{Introduction}

Free radicals are molecules with one or more unpaired electrons in their outer orbital. Most of these molecules are oxygen, nitrogen and iron centred compounds. They are highly unstable and react with adjacent molecules by donating, abstracting or sharing the unpaired electron(s). Often this mechanism, in the presence of reactive species, generates a cascade of free radicals (ROS, RNS, RIS) producing cellular damage. Generally the most diffuse reactions involve molecular oxygen so that toxic free radicals are termed oxidants. 
An antioxidant is considered a substance that at low concentration relative to oxidizable substrate counteracts the oxidative stress on the cell. Each organism has developed several antioxidant defence systems including proteins and low molecular-mass molecules. These nonprotein antioxidant molecules can act at many different stages in an oxidative sequence by removing directly or indirectly the reacting species. The scavenging of radicals is common among molecules or compounds belonging to the large group of dietary polyphenols present in plant oils. ${ }^{1,2}$ Often this type of antioxidants exhibit also a prooxidant activity which has been ascribed to formation of products and byproducts of phenol oxidation including semiquinone radicals, quinones, and reactive oxygen species (e.g., hydrogen peroxide and hydroxyl radicals) that induce cell damages. $3,4,5,6$

Hydroxytyrosol or 2-(3,4-dihydroxyphenyl)ethanol is a simple phenol extracted from olive oil and wine and now used as integrators and cosmetics. Studies on consumption of antioxidants from foods and in vitro studies on cells showed that hydroxytyrosol might contribute to the prevention of human diseases. ${ }^{7,8,9}$ Interestingly, at high molecular concentration, hydroxytyrosol inhibits or delay the rate of growth of a range of bacteria and fungi. ${ }^{10,11}$ Thus this simple phenol, as other molecules characterized by a catechol ring, shows antioxidant and prooxidant activities. We have studied the chemistry of hydroxytyrosol and its newly synthesized derivatives. Hydroxytyrosol has been assayed and beneficial properties have been observed at a concentration ranging from $50 \mu \mathrm{M}$ to $100 \mu \mathrm{M}$ whereas we observed a toxic effect of 2,5dihydroxytyrosol at $5 \mu \mathrm{M}$. At this concentration the activity of the new synthesized hydroxytyrosol derivative, obtained in high yield, has been compared to that of hydroxytyrosol and tyrosol. Interestingly the only structural relationship among such molecules is the number and position of hydroxyl groups participating in oxidation reactions.

\section{Results and Discussion}

Although the tetracetate derivative of 2,5-dihydroxytrosol has been previously described, ${ }^{9}$ no efficient method for its synthesis is still reported. Here we present a high yielding method to prepare 2,5-dihydroxytyrosol. Remarkably the present method is suitable further to prepare a number of hydroxytyrosol derivatives.

\section{Synthesis of the 2,5-dihydroxytyrosol}

The synthesis of 2,5-dihydroxytyrosol (4,5-dihydroxy-(2-hydroxyethyl)-phenol) has been carried out following Scheme 1. In the initial step the 3,4-dimethoxy-phenetyl alcohol (compound 2), easily prepared by a simple methylation of the phenol moiety of homovanillyl alcohol (compound 1), was protected as acetyl derivative in the alcoholic function and formylated in the C-6 position by a Friedel-Craft like reaction.

A simple and rapid $\mathrm{NaHSO}_{4}$ catalyzed oxidation by hydrogen peroxide gave the phenol compound 5. ${ }^{12}$ The phenol moiety was then protected as acetyl derivative and compound $\mathbf{6}$ was 
treated with $\mathrm{BBr}_{3}$ to promote the demethylation reaction. Simultaneously a selective deacetylation of the phenol moiety occurred and compound 7 was obtained in good yield (Scheme 1).<smiles>COc1cc(CCO)ccc1O</smiles>

1

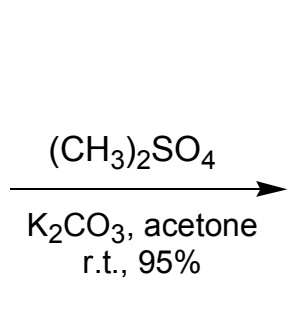<smiles>COc1ccc(CCO)cc1OC</smiles>

2

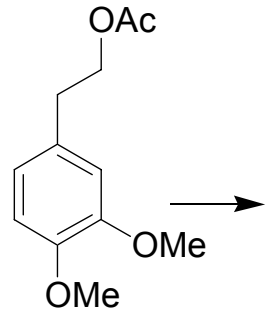

3

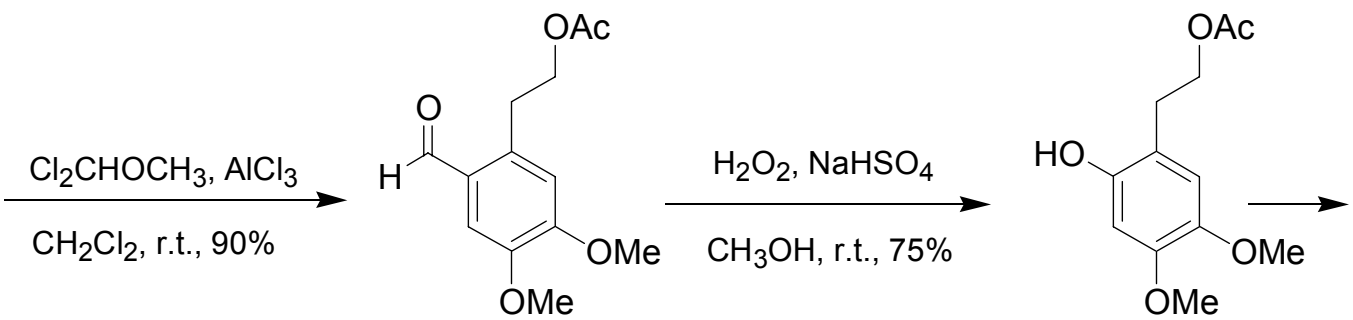

4 5<smiles>COc1cc(CCOC(C)=O)c(OC(C)=O)cc1OC</smiles>

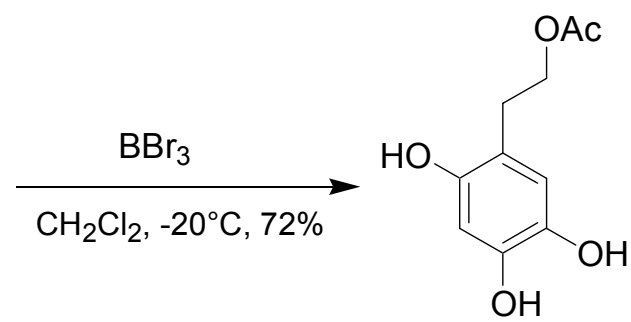

6

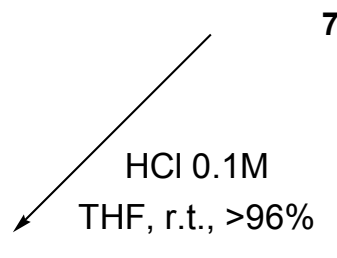

7<smiles>OCCc1cc(O)c(O)cc1O</smiles>
HF, r.t., $>96 \%$

Scheme 1. Synthesis of 2,5-dihydroxytyrosol.

Protection of compound $\mathbf{1}$ is required otherwise the formylation step should produce a formyl ester on the phenol moiety and not the desired electrophilic substitution at C-6. For the same 
reason the alcohol in the side chain of compound $\mathbf{2}$ had to be protected too. The alcoholic moiety was protected as acetyl derivative, which was not suitable for the phenol because of its incompatibility with the formylation reaction conditions. Thus, the phenol group of compound $\mathbf{1}$ was protected as methyl ether.

Compound 7 is the direct precursor of 2,5-dihydroxytyrosol (8). A simple hydrolytic step was used to deprotect the alcoholic moiety (Scheme 1).

To our knowledge compound 7 , obtained in a $42 \%$ overall yield by the present procedure, was not previously described. In a preceding work the tetra-acetate derivative of 7 was described as one of the products obtained in low yields, from hydroxytyrosol when submitted to oxidative conditions. ${ }^{13}$

\section{Inhibition of bacterial strains}

The inhibitory effects of Oleuropein and Hydroxytyrosol on bacteria and mycoplams, are well known, however, the antimicrobial dose-response effect depends on the microorganism species. In this work we studied the antibiotic resistance to 2,5-dihydroxytyrosol on the gram-negative Pseudomonas aeruginosa ATCC 27853 and Escherichia coli DH5 $\alpha$. Moreover we showed the activity on the gram-positive Streptococcus salivarius strain resistant to streptomycin (MIC 16 $\mu \mathrm{g} / \mathrm{ml}$ ) (Figures 1a and 1b).

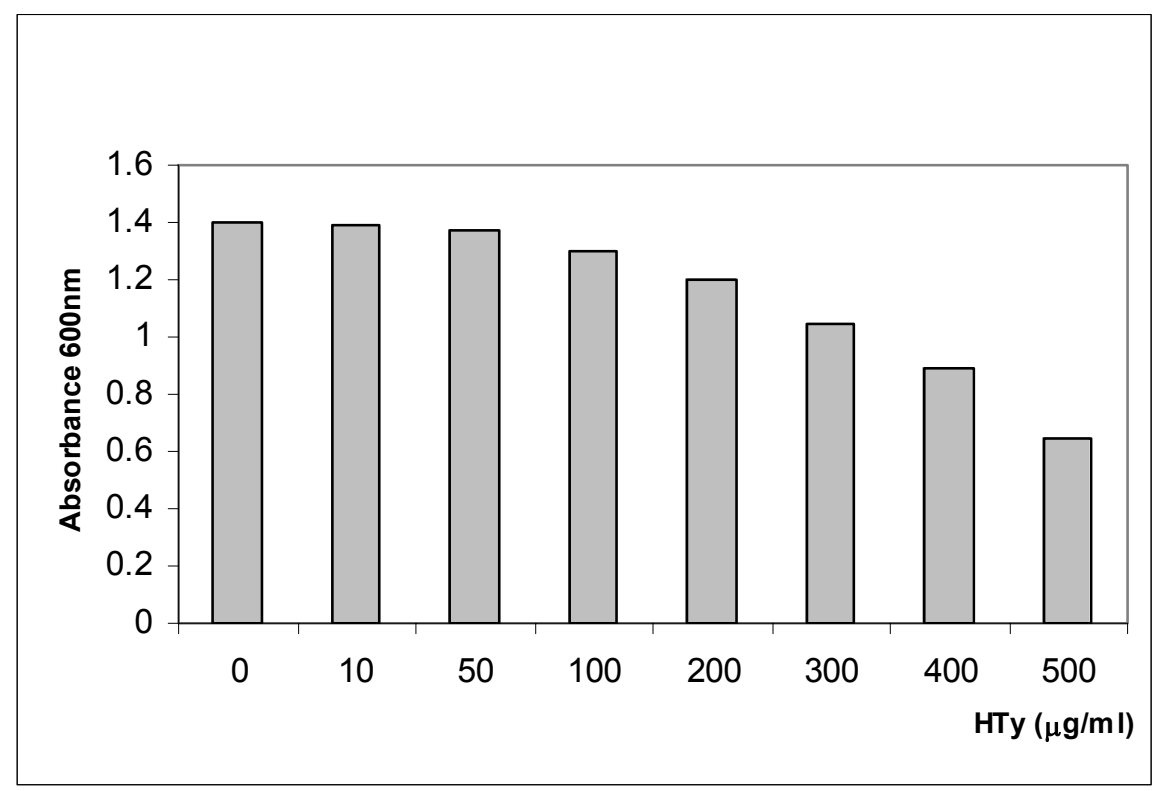

Figure 1a. An 1:100 aliquot from a over night culture was inoculated at $37^{\circ} \mathrm{C}$ in $\mathrm{M} 17$ medium in presence of increasing amounts of hydroxytyrosol (HTy). The cell density was measured as absorbance at $600 \mathrm{~nm}$. 


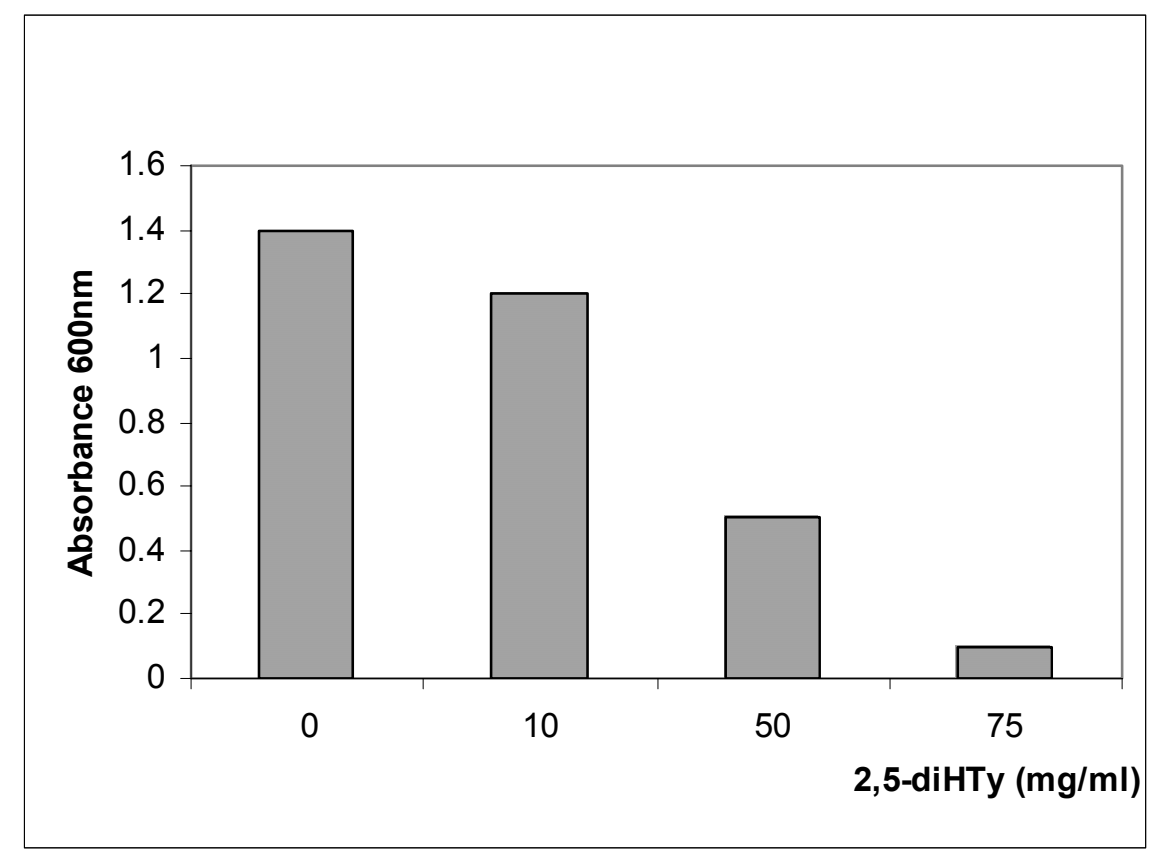

Figure 1b. An 1:100 aliquot from a over night culture was inoculated at $37^{\circ} \mathrm{C}$ in $\mathrm{M} 17$ medium in presence of increasing amounts of 2,5-dihydroxytyrosol (2,5di-HTy). The cell density was measured as absorbance at $600 \mathrm{~nm}$.

The growth of all studied bacteria, after $16 \mathrm{hrs}$ of incubation at $37^{\circ} \mathrm{C}$ in rich media, was inhibited in the presence of $10-50 \mu \mathrm{g} / \mathrm{ml}$ 2,5-dihydroxytyrosol. However, in these experimental conditions after $96 \mathrm{hrs}$ all bacteria showed development of resistant cells. Interestingly at a concentration of $80 \mu \mathrm{g} / \mathrm{ml}, 2,5$-dihydroxytyrosol resulted in a complete inhibition of bacterial growth of both gram-negative and gram-positive strains without development of resistant cells after 96 hrs of incubation.

\section{Inhibition of SH-SY5Y cells growth}

To evaluate the effect of the new synthesised hydroxytyrosol derivative $\mathbf{8}$ on human cells we used the SY-SH5Y human dopaminergic neuroblastoma cell line. It is a third generation neuroblastoma cell line, which was originally isolated from a woman's metastatic bone tumor in 1970. This cell line is considered a good pharmacological model to study neurodegenerative disorders, including damages from oxidative stress.

Since there are not reports about the effect of hydroxytyrosol on SY-SH5Y, in this work we compared its activity to that of its derivative $\mathbf{8}$ and to that of tyrosol. Our results showed that 2,5dihydroxytyrosol is more cytotoxic than hydroxytyrosol whereas tyrosol has a slight inhibitory activity. After $24 \mathrm{~h}$ incubation of SH-SY5Y cells in the presence of $5 \mu \mathrm{M}$ tyrosol or hydroxytyrosol, both molecules showed a modest, though significant, anti-proliferative effect on cell viability compared to untreated cells. After treatment the percentage of viable cells is around 
$85 \%$. At the same concentration, 2,5-dihydroxytyrosol inhibited about $35 \%$ of cell growth likely retaining a prooxidant activity that is currently under investigation (fig. 2).

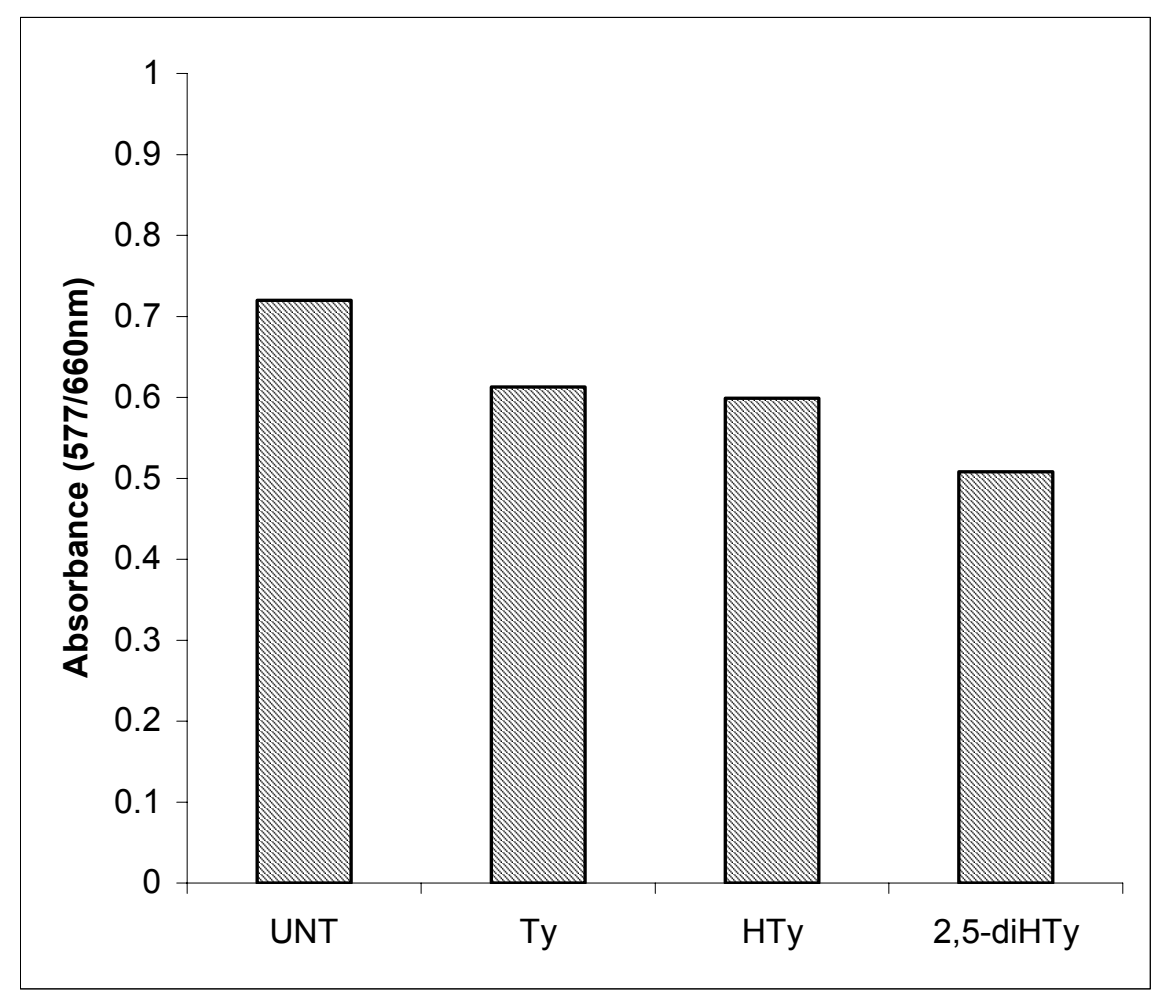

Figure 2. SH-SY5Y neuroblastoma cells proliferation in presence of tyrosol (Ty), hydroxytyrosol (HTy) and 2,5-dihydroxytyrosol (2,5-diHTy). Cells were seeded at a density of 15000 cells/well in 96-well microplates. After 48 hours the medium was changed to that containing $5 \mu \mathrm{M}$ of each phenol and the cells were grown for an additional 24 hours. Cell proliferation was estimated by the MTT method.

However the protective effect of hydroxytyrosol on tumoral cell line appeared to be very low, but it should be considered that it was assayed in presence of DMSO likely decreasing its antioxidant property.

Preparation of new derivatives is in progress in order to elucidate a possible development and effectiveness as lead compounds of tumor cell lines growth inhibitors.

In our experiments hydroxytyrosol and its derivative 2,5-dihydroxytyrosol have a toxic effect on different cell systems and at low dose levels. These results are in agreement with previous data on structurally related antioxidants, possessing a cathecol ring. The main effect of toxicity for these compounds has been described mediated by transition metals and our medium of cell cultures are not metal free. Oxidized phenol radicals could promote lipid peroxidation and DNA breaks. Beside the possible mechanism of toxicity, hydroxytyrosol has been described to be an antioxidant at a concentration around $50 \mu \mathrm{M}$, as previously reported. ${ }^{14,15}$ On the other hand, other 
reports showed that the antibiotic activity of hydroxytyrosol range up $0.5 \mathrm{mg} / 1(0.5 \mathrm{mM})$ hydroxytyrosol (90\% inhibition of mycoplasma) and more than $500 \mathrm{mg} / \mathrm{l}(3 \mathrm{mM})$ to kill some bacterial resistant strains. ${ }^{10,11}$ We found that 2,5-dihydroxytyrosol, at $80 \mu \mathrm{g} / \mathrm{ml}(5 \mu \mathrm{M})$ shows a broad spectrum of activity inhibiting bacteria as well as it delays neuroblastoma cell duplication. We did not investigate the mechanism of toxicity of the molecules used in this study since the prooxidant effect of many polyphenols has been described to be metal-dependent. In our experiments we have not used metal-free media but we observed that the toxicity of studied molecules increases with the number of hydroxyl groups (Table 1). Indeed the main differences among structures of tyrosol, hydroxytyrosol and 2,5-dihydroxytyrosol are in the number and position of hydroxyl groups on the aromatic ring. Since 2,5-dihydroxytyrosol can be further functionalised, the present method permits to approach the synthesis of other hydroxytyrosol derivatives. Moreover the increased toxicity of the new molecule could suggest that the number and position of hydroxyl groups are important to stabilize phenoxyl radicals thus resulting in higher prooxidative effect of these simple phenols.

Table 1. Percentage of growth inhibition as function of active hydroxyl groups on phenols

number of $\mathrm{OH}$ groups $\quad$ Cell growth inhibition (\%)




\section{Experimental Section}

\section{Synthesis of 2,5-dihydroxytyrosol}

All general reagents were purchased from Sigma-Aldrich, Mallickrodt-Baker or Carlo Erba, if not otherwise specified. Compound 2 was synthesized starting from homovanillyl alcohol, but it is also commercially available from Sigma-Aldrich Co.

4,5-Dimethoxy-2-(ethyl-methylester)-benzaldehyde (4). In a $50 \mathrm{ml}$ round bottom flask, 256 $\mathrm{mg}(1.4 \mathrm{mmol})$ of (3,4-dimethoxy)-phenetyl alcohol acetate (3), $386 \mathrm{mg}$ (2.9 mmol) of $\mathrm{AlCl}_{3}$ and $20 \mathrm{ml}$ of anhydrous methylene chloride were added. The mixture was stirred in an ice bath, then a solution of $\mathrm{Cl}_{2} \mathrm{CHOCH}_{3}(280 \mathrm{mg}, 3.5 \mathrm{mmol})$ in anhydrous $\mathrm{CH}_{2} \mathrm{Cl}_{2}(5 \mathrm{ml})$ was added dropwise. When all the reagents were added, the reaction mixture was left at room temperature and stirred for additional $2 \mathrm{hr}$. The mixture was then quenched with ice and stirred until a change of the colour was observed. The solvent was removed under vacuum and the aqueous residue was extracted with EtOAc. The organic extracts were collected and washed with brine until neutrality, then dried over anhydrous $\mathrm{Na}_{2} \mathrm{SO}_{4}$ and the solvent removed under vacuum. The product 4 (282 mg, 90\%) was obtained pure (NMR analysis) as an oil. ${ }^{1} \mathrm{H}-\mathrm{NMR}(200 \mathrm{MHz}$, $\left.\mathrm{CDCl}_{3}\right) \delta(\mathrm{ppm}): 1.89(3 \mathrm{H}, \mathrm{s}), 3.19(2 \mathrm{H}, \mathrm{t}, J=7 \mathrm{~Hz}), 3.80(3 \mathrm{H}, \mathrm{s}), 3.83(3 \mathrm{H}, \mathrm{s}), 4.16(2 \mathrm{H}, \mathrm{t}, J=7$ $\mathrm{Hz}), 6.64(1 \mathrm{H}, \mathrm{s}), 7.24(1 \mathrm{H}, \mathrm{s}), 10.0(1 \mathrm{H}, \mathrm{s}) .{ }^{13} \mathrm{C}-\mathrm{NMR}\left(50 \mathrm{MHz}, \mathrm{CDCl}_{3}\right) \delta(\mathrm{ppm}): 20.5,30.6$, $55.7,55.9,64.5,112.1,113.3,127.2,135.1,147.9,163.4,170.4,189.8$. Anal. calcd for $\mathrm{C}_{13} \mathrm{H}_{16} \mathrm{O}_{5}$ : C, 61.90; H, 6.39. Found: C, 61.95; H, 6.42.

(3,4-Dimethoxy-6-hydroxy)-phenetyl alcohol acetate (5). To a mixture of 4,5-dimethoxy-2(ethyl-methylester)-benzaldehyde (329 mg, $1.5 \mathrm{mmol}$ ) and $\mathrm{NaHSO}_{4}(25 \mathrm{mg}, 0.2 \mathrm{mmol})$ in methanol (15 ml), a 50\% water solution of $\mathrm{H}_{2} \mathrm{O}_{2}(0.22 \mathrm{ml}, 3.8 \mathrm{mmol})$ was added.

After $30 \mathrm{~min}$ the substrate was completely consumed and only a new product was observed by TLC analysis. The solvent was removed under vacuum, and the residue extracted with EtOAc. The organic phase was washed with brine until neutrality, then dried over anhydrous $\mathrm{Na}_{2} \mathrm{SO}_{4}$ and the solvent evaporated under vacuum. The crude product was purified by flash chromatography on silica gel eluting with a 1:1 hexane/EtOAc solution. Compound 5 (268 mg, 75\%) was obtained as a colourless oil. ${ }^{1} \mathrm{H}-\mathrm{NMR}\left(200 \mathrm{MHz}, \mathrm{CDC}_{13}\right) \delta(\mathrm{ppm}): 2.07(3 \mathrm{H}, \mathrm{s}), 2.87$ $(2 \mathrm{H}, \mathrm{t}, J=7 \mathrm{~Hz}), 3.80(6 \mathrm{H}, \mathrm{s}), 4.23(2 \mathrm{H}, \mathrm{t}, J=7 \mathrm{~Hz}), 6.47(1 \mathrm{H}, \mathrm{s}), 6.60(1 \mathrm{H}, \mathrm{s}) .{ }^{13} \mathrm{C}-\mathrm{NMR}(50$ $\left.\mathrm{MHz}, \mathrm{CDCl}_{3}\right) \delta(\mathrm{ppm}): 21.0,29.6,55.9,56.8,64.7,101.4,114.8,114.9,142.7,148.8$ (2 C), 171.8. Anal. calcd for $\mathrm{C}_{12} \mathrm{H}_{16} \mathrm{O}_{5}$ : C, 59.99; H, 6.71. Found: C, 60.02; H, 6.75.

2-Hydroxy-4,5-dimethoxy-phenetyl acetate (6). Phenol $5(250 \mathrm{mg})$ was treated with a solution of $1 \mathrm{ml}$ of pyridine and $1 \mathrm{ml}$ of $\mathrm{Ac}_{2} \mathrm{O}$ and left at room temperature overnight. The reaction was quenched with ice, treated with a $2 \mathrm{M}$ solution of $\mathrm{HCl}$ until the water layer was acidic, and extracted with EtOAc. The extracts were washed with a saturated solution of $\mathrm{NaHCO}_{3}$ until the water layer was basic, and then neutralised washing with brine. The organic phase was dried over anhydrous $\mathrm{Na}_{2} \mathrm{SO}_{4}$ and the solvent removed under vacuum. $260 \mathrm{mg}$ ( $>95 \%$ ) of compound 6 was obtained and used without further purification. 
2,4,5-Trihydroxy-phenetyl acetate (7). To a solution of 2-hydroxy-4,5-dimehtoxy-phenetyl acetate $6(2.82 \mathrm{~g}, 10 \mathrm{mmol})$ in $10 \mathrm{ml}$ of $\mathrm{CH}_{2} \mathrm{Cl}_{2}$ at $-20^{\circ} \mathrm{C}$, a $1 \mathrm{M}$ solution of $\mathrm{BBr}_{3}$ in $\mathrm{CH}_{2} \mathrm{Cl}_{2}(2.5$ $\mathrm{g}, 20 \mathrm{mmol}$ ) was added dropwise. After $6 \mathrm{hrs}$ the substrate was completely consumed. The mixture was quenched with ice and rapidly extracted with EtOAc. The organic solution was washed with water until $\mathrm{pH}=4$, then dried over anhydrous $\mathrm{Na}_{2} \mathrm{SO}_{4}$ and the solvent removed under vacuum.

The final product was quickly purified by a short column chromatography on silica gel eluted with a 1:4 mixture of hexane / EtOAc. $1.52 \mathrm{~g} \mathrm{(72 \% )}$ of 7 were obtained as a colourless oil. ${ }^{1} \mathrm{H}$ NMR (200 MHz, CDC 13$) \delta(\mathrm{ppm}): 1.90(3 \mathrm{H}, \mathrm{s}), 3.18(2 \mathrm{H}, \mathrm{t}, J=6.8 \mathrm{~Hz}), 4.15(2 \mathrm{H}, \mathrm{t}, J=6.8 \mathrm{~Hz})$, $6.61(1 \mathrm{H}, \mathrm{s}), 6.62(1 \mathrm{H}, \mathrm{s}) .{ }^{13} \mathrm{C}-\mathrm{NMR}\left(50 \mathrm{MHz}\right.$, acetone-d $\left.{ }_{6}\right) \delta(\mathrm{ppm}): 21.8,50.8,66.7,105.2$, 116.4, 118.2, 139.5, 145.9, 150.1, 172.4. Anal. calcd for $\mathrm{C}_{10} \mathrm{H}_{12} \mathrm{O}_{5}$ : C, 56.60; H, 5.70. Found: C, $56.63 ; \mathrm{H}, 5.72$.

When necessary, compound 7 was protected as tetracetate and purified as such by chromatography (eluting with hexane/ethyl acetate 9:1) before the next step.

2,5-Dihydroxytyrosol (8). To a solution of 2,4,5-trihydroxy-phenetyl acetate (7) (2.12 g, 10 $\mathrm{mmol})$ or the corresponding tetracetate, in THF $(25 \mathrm{ml})$, a $5 \mathrm{M}$ solution of $\mathrm{HCl}$ in water $(25 \mathrm{ml})$ was added and left to react under stirring for $12 \mathrm{hrs}$ at room temp. The course of the reaction was monitored by TLC analysis. When the reaction was complete, the solvent was evaporated in vacuum to furnish compound $8(1.65 \mathrm{~g},>95 \%)$ which resulted pure by NMR analysis and not needed of further purification. ${ }^{1} \mathrm{H}-\mathrm{NMR}\left(200 \mathrm{MHz}, \mathrm{CD}_{3} \mathrm{OD}\right) \delta(\mathrm{ppm}): 2.40(2 \mathrm{H}, \mathrm{t}, J=7 \mathrm{~Hz}), 3.40$ $(2 \mathrm{H}, \mathrm{t}, J=7 \mathrm{~Hz}), 6.05(1 \mathrm{H}, \mathrm{s}), 6.25(1 \mathrm{H}, \mathrm{s}) .{ }^{13} \mathrm{C}-\mathrm{NMR}\left(50 \mathrm{MHz}, \mathrm{CD}_{3} \mathrm{OD}\right) \delta(\mathrm{ppm}): 34.4,63.7$, $104.9,117.5,118.6,138.8,145.1$, 149.4. Anal. calcd for $\mathrm{C}_{8} \mathrm{H}_{10} \mathrm{O}_{4}$ : C, 56.47; H, 5.92. Found: C, $56.44 ; \mathrm{H}, 5.90$.

\section{Inhibition of bacterial strains}

Streptoccocus salivarius, Pseudomonas aeruginosa and Escherichia coli were grown in M17 medium, in Mueller-Hinton broth (MHB) and LB (Luria Broth), respectively (Difco, Detroit, Mich.). Each strain was plated on agar plates and single colony picked to grow in liquid medium at $37^{\circ} \mathrm{C}$ for about $16 \mathrm{hrs}$.

Inhibition of bacterial growth was studied on Pseudomonas aeruginosa ATCC 27853, Streptococcus salivarius sp. and Escherichia coli DH5a.

In all experiments a single colony was grown in its specific medium for about $16 \mathrm{hrs}$ and after that an aliquot 1: 50 of each cell culture was inoculated with increasing doses (from 10 $\mu \mathrm{g} / \mathrm{ml} \mathrm{up}$ to $1 \mathrm{mg} / \mathrm{ml}$ ) of hydroxytyrosol or 2,5-dihydroxytyrosol, respectively. An aliquot of culture was again incubated for $16 \mathrm{hr}$ for observation of growth inhibition.

The experiments were repeated three times and each cell culture was further incubated up to 96 $\mathrm{hr}$ to test development of resistant strains. 


\section{Inhibition of SH-SY5Y cell growth}

Human dopaminergic neuroblastoma cell line SH-SY5Y was obtained by the Cell Bank ICLC (Genova, Italy). The cells were maintained in a humidified incubator under $5 \% \mathrm{CO}_{2}$ at $37^{\circ} \mathrm{C}$, and were grown in Dulbecco's modified Eagle's/F12 medium supplemented with 10\% heatinactivated fetal bovine serum and $2 \mathrm{mM}$ glutamine. Tissue culture reagents were from Gibco BRL (Milan, Italy). The cells were routinely harvested twice a week by tripsinization $(0.05 \%$ tripsin-EDTA) and plated in $25 \mathrm{~cm}^{2}$ culture flasks (split 1:6-1:8).

Test compounds were dissolved in DMSO at a concentration of $20 \mathrm{mM}$. They were then diluted to a concentration of $1 \mathrm{mM}$ in culture medium and then sterilized by passing through $0.22 \mu \mathrm{m}$ syringe filters. The test compounds were further diluted to the desired final concentration in culture medium immediately before performing each experiment. Control experiments were performed with the use of the solvent alone. DMSO at the tested concentrations had no effect on the viability of SH-SY5Y cells.

Cell viability was evaluated by using the dye [4,5-dimethylthiazol-2-yl]-2,5-diphenyltetrazolium bromide (MTT). The assay is based on the ability of living cells to convert dissolved MTT into insoluble formazan, whose amount is proportional to the number of living cells. Cells were seeded in 96-well plates in $100 \mu \mathrm{l}$ medium at a density of 15,000 cells/well. The cultures were grown for $48 \mathrm{~h}$, then the medium was changed to that containing tyrosol, hydroxytyrosol or its derivative (8) at final concentration of $5 \mu \mathrm{M} ; 2,5$-dihydroxytyrosol was also tested at $10 \mu \mathrm{M}$. After incubation for $24 \mathrm{~h}, 20 \mu \mathrm{l}$ of MTT reagent $(5 \mathrm{mg} / \mathrm{mL}$ in phosphate buffered saline solution (PBS)) were added to each well and incubated for $2 \mathrm{~h}$ at $37^{\circ} \mathrm{C}$. The medium was then discarded and the resulting formazan dye was extracted with $100 \mu \mathrm{L}$ isopropanol. The absorbance was measured in a spectrophotometric microplate reader at a wavelength of $577 \mathrm{~nm}$, with a reference at $660 \mathrm{~nm}$. Wells without cells were used as blanks and were subtracted as background from each sample.

\section{Conclusions}

The present work shows an expedient synthesis of 2,5-dihydroxytyrosol. Apparently an additional hydroxyl group promotes an antioxidant to pro-oxidant switch of hydroxytyrosol, as suggested by inhibitory activity of 2,5-dihydroxytyrosol on bacteria and human tumour cell line. As this method permits to prepare new compounds, we are exploring the possibilities of synthesising new biologically active hydroxytyrosol derivatives. 


\section{Acknowledgements}

The financial support from the Italian Ministry for University and Research, General Management for Strategies and Development of Internationalization of Scientific and Technological Research, is gratefully acknowledged.

\section{References}

1. Bianco, A.; Serrilli A. M.; Melchioni C. ARKIVOC 2007, (vii), 146.

2. Can Başer, K. H.; Demirci B. ARKIVOC 2007, (vii), 335.

3. Galati, G.; Sabzevari, O.; Wilson, J. X.; O’Brien, P. J. Toxicology 2002, 177, 91.

4. Sakihama, Y.; Cohen, M. F.; Grace, S. C.; Yamasaki, H. Toxicology 2002, 177, 67.

5. Siraki, A. G.; Peter, J. Toxicology 2002, 177, 81.

6. Barbehenn, R.; Cheek, S.; Gasperut, A.; Lister, E.; Maben, R. J. Chem. Ecol. 2005, 31, May.

7. Bianco, A.; Chiacchio, M. A.; Grassi, G.; Iannazzo, D.; Piperno, A.; Romeo, R. Food Chemistry 2006, 95, 562.

8. Carluccio, M. A.; Siculella, L.; Ancora, M. A.; Massaro, M.; Scoditti, E.; Storelli, C.; Visioli, F.; Distante, A.; De Caterina, R. Arterioscler. Thromb. Vasc. Biol. 2003, 23, 622.

9. Faine, L. A.; Rodrigues, H.; Galhardi, C. M.; Ebaid, G. M.; Diniz, Y. S.; Padovani, C. R.; Novelli, E. L. Can. J. Physiol. Pharmacol. 2006, 84, 239.

10. Bisignano, G.; Tomaino, A.; Lo Cascio, R.; Crisafi, G.; Uccella, N.; Saija, A. J. Pharm. Pharmacol. 1999, 51, 971.

11. Furneri, P. M.; Piperno, A.; Sajia, A.; Bisignano, G. Antimicrob. Agents Chemother. 2004, $48,4892$.

12. Matsumoto, M.; Kobayashi, K.; Hotta, Y. J. Org. Chem. 1984, 49, 4740.

13. De Lucia, M.; Panzella, L.; Pezzella, A.; Napolitano A.; D'Ischia, M. Tetrahedron 2006, 62, 1273.

14. Manna, C.; Galletti, P.; Cucciolla, V.; Montedoro, G.; Zappia, V. J. Nutr. Biochem. 1999, 10,159 .

15. Hashimoto, T.; Ibi, M.; Matsuno, K.; Nakashima, S.; Tanigawa, T.; Yoshikawa, T.; YabeNishimura, C. Free Rad. Biol. Med. 2004, 36, 555. 